\section{Mystery of Rainbow Warrior}

LAST month's sinking in New Zealand of Rainbow Warrior, flagship of the Greenpeace environmental organization, and the killing of the ship's photographer, have stirred a murky pot of accusation and counter-accusation in France. The French press has taken the scandal to its heart.

One of the more speculative magazines, $V S D$, has even gone so far as to accuse the Elysée palace (the French White House) of having organized the attack to demonstrate French power in the Pacific and determination to continuef nuclear weapons testing on Muroroa Atoll; all might have gone well, the theory goes, had not a mole from the British secret service, MI5, buried within its French equivalent, DGSE, tipped off the New Zealand authorities (somewhat too late, it must be assumed). The Elysée will be suing VSD,

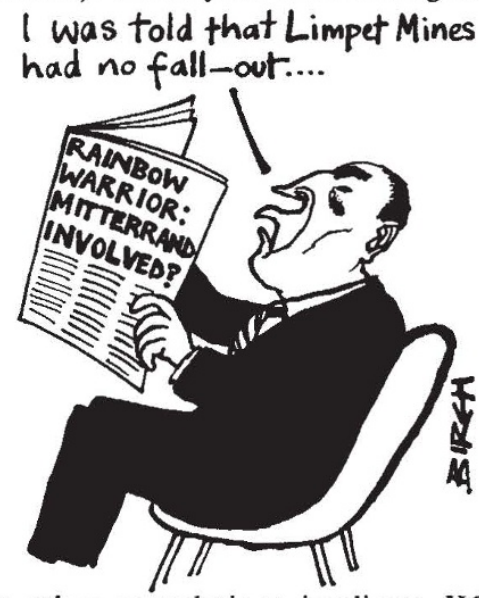

but other speculations implicate KGB, CIA, the home-grown French extreme right and other supposed enemies of equilibrium.

In the more serious French press, a picture is emerging that the two people held and now formally accused in New Zealand are probably members of the French Army seconded to DGSE to survey the activities of Greenpeace. It is suggested that the frogmen who attached two limpet mines to Rainbow Warrior left behind their French inflatable dinghy and bubblefree breathing apparatus (stamped "Made in France") and probably escaped in a hired yacht, Ouvea, belonged to a separate French group.

The bombers themselves, like Ouvea, may have come from New Caledonia, the group of French Pacific islands which is fast becoming President Mitterrand's Algeria - a country peopled by some 91,000 native Kanaks seeking independence and wooed by M. Mitterrand but also 54,000 French colonists who are determined the island shall stay French. These French might have wished to discredit the present government - and hence the trail of evidence left behind, it is suggested.

However, this relatively convenient picture is inconsistent with the fact that and to inform the public.
Ouvea was hired (for FF 70,000 cash) through a Paris agency. The hirers were an adventurist French doctor (who specializes in diving medicine, but who left Ouvea before the attack and claims he knew nothing of the object of the mission) and three more shadowy figures, since disappeared with the yacht.

The Rainbow Warrior crew also believes there was a French "mole" aboard, a woman who sent articles for a "French paper" and one of whose maps of New Zealand waters was later found on Ouvea (when the yacht was briefly stopped and then released, to the later chagrin of the New Zealand police). This woman has also disappeared, via, apparently, an archaeological dig in Israel.

President Mitterrand has asked M. Bernard Tricot to carry out an investigation

But if indeed the French secret service does prove deeply involved, what possible government motive - or perception by junior officials of a government motive could there have been to bomb Rainbow Warrier? The only possibility could be to protect the French nuclear weapons tests on Mururoa, not far from New Caledonia

and Tahiti, which Greenpeace intended to disrupt. The French nuclear arsenal is in continual evolution and even expansion with a postulated introduction of "enhanced radiation weapons" or neutron bombs and a testing campaign of at least another 15 years is planned. Speculation by the French that Rainbow Warrior was carrying sophisticated devices for detecting neutron bombs (discounted by Greenpeace, which says the ship carried only a geiger counter and apparatus for relaying pictures to news agencies) suggests that perhaps France was indeed planning a neutron weapon testing programme.

But whatever the merits of this speculation and of an attack on Greenpeace as a counter-measure, the opposition of South Pacific states to French testing, at the rate of 60 weapons between 1977 and 1984, is now liable to increase, since the signing earlier this month by seven nations of a declaration that the South Pacific should be a "nuclear free zone". The treaty, which forbids signatories to build or test nuclear weapons, will be ratified by the end of the year, Australian Prime Minister Bob Hawke has predicted, and though powerless to prevent French testing in the region it will certainly increase French political isolation. The Rainbow Warrior affair can only have done the same

Robert Walgate

\title{
French mistrusted on Mururoa
}

Mururoa Atoll, according to New Zealand and Australian scientists who visited the French nuclear weapons testing site in October 1983, is likely to release its accumulated load of debris from underground explosions to the Pacific "within $500-1,000$ years".

At present, they say, emissions from the island and consequent fallout in the South Pacific region are having a negligible effect on health and they do not suggest that even the likely release of the contained radiation within a few centuries will be "consequential". But the scientists' evident suspicion of French calculations about the security of the site is symptomatic of the South Pacific's distaste for what the French are doing with "their" atoll.

For example, "French information on venting is very qualititative", the South Pacific scientists say in their report, "and there is no reason to believe their figure that more than 99 per cent of the radioactivity is retained in vitrified material". And any "implicit impression" that venting is barely detectable is "almost certainly false".

On underground containment, the report indicates that the French tests are "probably" 700-1,200 $\mathrm{m}$ below the bottom of the lagoon, in the volcanic base of the atoll, which is surmounted by $180-500 \mathrm{~m}$ thickness of limestone. But the limestones contain some highly porous sections and the volcanics are fractured for $400 \mathrm{~m}$ around each explosion. "The volcanics in their virgin state offer a poor to moderate geochemical barrier and a moderate to good hydrological barrier. "The testing programme is reducing the effectiveness of both", the report says. Moreover, "the claim that the transition zone [between the volcanics and the porous limestone] acts as a barrier to long-term leakage can, on the basis of geological evidence, be discounted".

Thus there will be leakage within 5001,000 years, in which transuranic elements without a particular geochemical affinity (such as neptunium-237) may be expected to be leached out. "It would be surprising if this leakage were consequential", the report says, but such scientific assurances, according to an Australian government spokesman last week, have made very little impression on public opinion. Rational or irrational, the public view is that far more atomic weapons have now been exploded in the South Pacific than in the north (the public thinks of Hiroshima and Nagasaki) and that it is simply high time the bombing stopped.

But France will not stop, which may, in the long run, lead to a search for a new site. A deal with French Africa to use the Sahara (from which the testers decamped to Muroroa in 1966), or a deal with the United States to use its own sites, emerge as the only faint possibilities.

Robert Walgate 